\title{
THE 12,460-YEAR HOHENHEIM OAK AND PINE TREE-RING CHRONOLOGY FROM CENTRAL EUROPE-A UNIQUE ANNUAL RECORD FOR RADIOCARBON CALIBRATION AND PALEOENVIRONMENT RECONSTRUCTIONS
}

\author{
Michael Friedrich ${ }^{1} \cdot$ Sabine Remmele $^{1} \bullet$ Bernd Kromer $^{2}$ - Jutta Hofmann ${ }^{1} \bullet$ Marco Spurk $^{1} \bullet$ \\ Klaus Felix Kaiser ${ }^{3} \cdot$ Christian Orcel $^{4} \cdot$ Manfred Küppers $^{1}$
}

\begin{abstract}
The combined oak and pine tree-ring chronologies of Hohenheim University are the backbone of the Holocene radiocarbon calibration for central Europe. Here, we present the revised Holocene oak chronology (HOC) and the Preboreal pine chronology (PPC) with respect to revisions, critical links, and extensions. Since 1998, the HOC has been strengthened by new trees starting at 10,429 $\mathrm{BP}(8480 \mathrm{BC})$. Oaks affected by cockchafer have been identified and discarded from the chronology. The formerly floating PPC has been cross-matched dendrochronologically to the absolutely dated oak chronology, which revealed a difference of only 8 yr to the published ${ }^{14} \mathrm{C}$ wiggle-match position used for IntCal98. The 2 parts of the PPC, which were linked tentatively at 11,250 BP, have been revised and strengthened by new trees, which enabled us to link both parts of the PPC dendrochronologically. Including the 8-yr shift of the oak-pine link, the older part of the PPC (pre-11,250 BP) needs to be shifted $70 \mathrm{yr}$ to older ages with respect to the published data (Spurk 1998). The southern German part of the PPC now covers $2103 \mathrm{yr}$ from 11,993-9891 BP (10,044-7942 BC). In addition, the PPC was extended significantly by new pine chronologies from other regions. A pine chronology from Avenches and Zürich, Switzerland, and another from the Younger Dryas forest of Cottbus, eastern Germany, could be crossdated and dendrochronologically matched to the PPC. The absolutely dated tree-ring chronology now extends back to $12,410 \mathrm{cal} \mathrm{BP}(10,461 \mathrm{BC})$. Therefore, the tree-ring-based ${ }^{14} \mathrm{C}$ calibration now reaches back into the Central Younger Dryas. With respect to the Younger Dryas-Preboreal transition identified in the ring width of our pines at 11,590 BP, the absolute tree-ring chronology now covers the entire Holocene and $820 \mathrm{yr}$ of the Younger Dryas.
\end{abstract}

\section{THE NEW HOLOCENE OAK CHRONOLOGY (HOC)}

The long tree-ring chronologies of the Hohenheim laboratory are based on sub-fossil trees found in Quaternary deposits of the large rivers of central Europe (Becker 1982; Friedrich et al. 1999). We sampled mainly oaks (Quercus robur L.; Q. petraea M.) and pines (Pinus sylvestris L.) exposed in gravel pits of southern Germany. Both genera form resistant heartwood, which helps preservation in anaerobic conditions over thousands of years. The trees are remnants of former riparian forests which were eroded and buried by fluvial activity. They are rarely found in situ, but the good condition of most of the trunks, with traces of branches and roots, shows that they did not drift over long distances but were quickly buried in sediment. Therefore, the stands of the trees can be localized to the lower terraces of the rivers.

The sites where subfossil oaks were found are shown in Figure 1. They are located along the southern German river valleys Rhine, Main, Danube, and tributaries and from the eastern German river valleys Spree, Saale, and Elster.

The individual ages of the subfossil oaks are surprisingly short. The mean age of all sampled oaks is only $176 \mathrm{yr}$, with a maximum age of $575 \mathrm{yr}$. Some $97 \%$ of all trees were younger than $300 \mathrm{yr}$ (Figure 2). This fact is related to the regular occurrence of floods connected with extensive erosion, which often disturbed riparian forests. On the other hand, the good growing conditions on the floodplains, especially after the mid-Holocene, allowed large annual growth increments resulting in huge, but young, trees with a stem diameter of more than $1 \mathrm{~m}$. Most of those trees were killed long before their potential biological age through erosion, or they collapsed under their own weight.

${ }^{1}$ Institute of Botany (210), Hohenheim University, D-70593 Stuttgart, Germany.

${ }^{2}$ Heidelberg Academy of Sciences, INF 229, D-69120 Heidelberg, Germany.

${ }^{3}$ Swiss Federal Research Institute WSL, CH-8903 Birmensdorf / Geographic Dept., University of Zürich, CH 8057 Zürich, Switzerland.

${ }^{4}$ Laboratoire Romand de Dendrochronologie, CH-1510 Moudon, Switzerland 


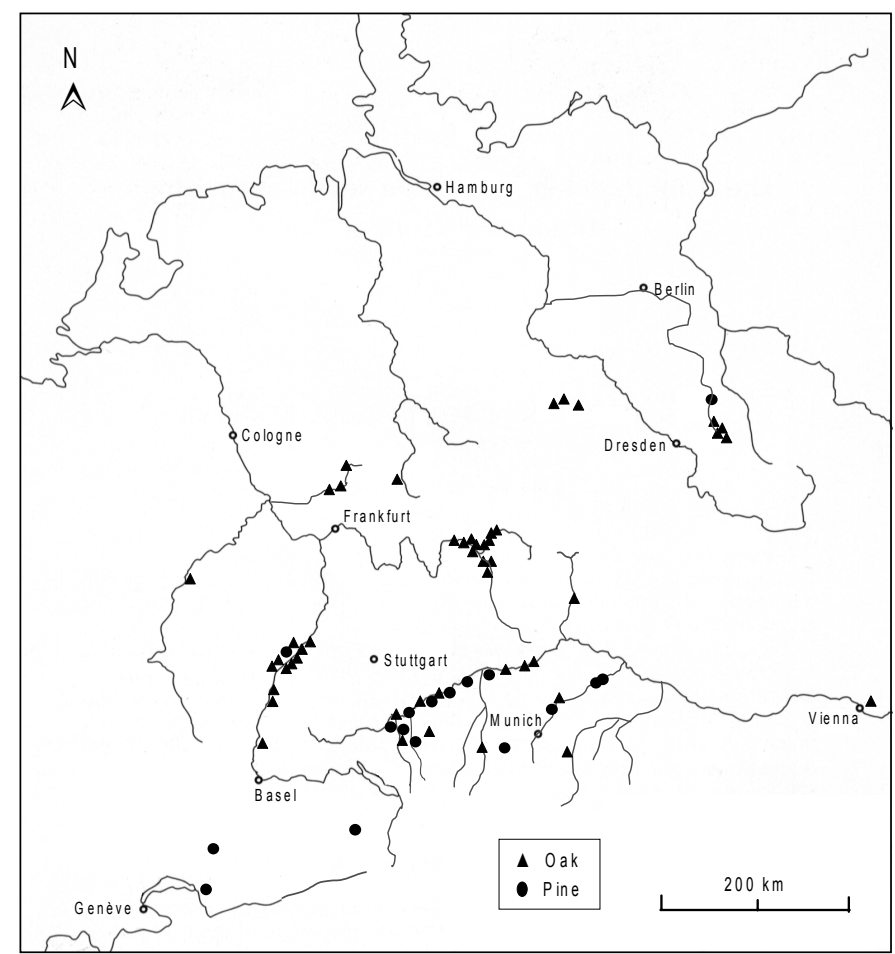

Figure 1 Location of the sites where subfossil oaks and pines were found. The sites mapped are of living oaks; historical and archaeological samples are not mapped. The sites are spread throughout southern Germany.

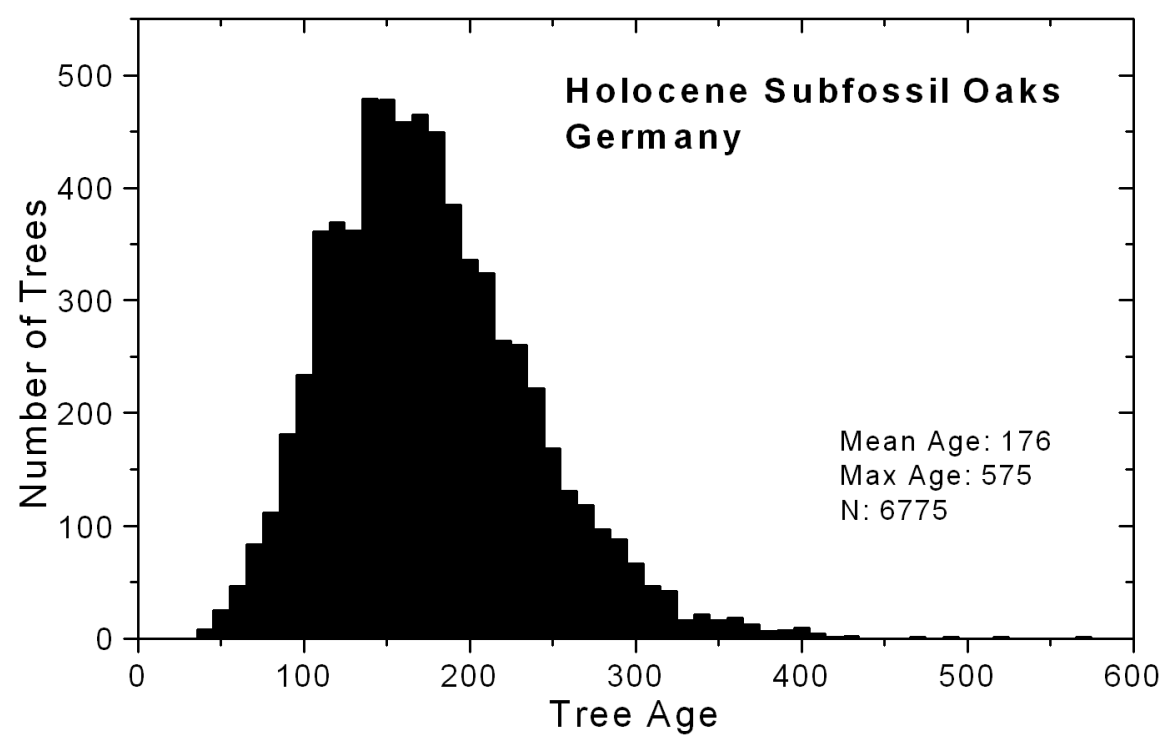

Figure 2 Distribution of individual tree ages of 6775 sampled subfossil oaks from southern and eastern Germany. Due to regular disturbance of forests in the river valleys, the mean age of all sampled subfossil oaks is only $176 \mathrm{yr}$. Only a few oaks reach ages of more than $350 \mathrm{yr}$, the longest having 575 rings. 
The sample density through time shows marked fluctuations, which are a result of the variable sedimentation and preservation of trees during the Holocene (Spurk et al. 2002) (Figure 3). The fluctuations in the numbers of subfossil oaks from river sediments reflect the changes in the hydrological regime of the river systems over time. If the number of trees is sufficiently high to be statistically valid, the density fluctuations can be used to infer the deposition rate as well as geomorphological and paleoecological changes of the river valley during the Holocene (Spurk et al. 2002; Becker 1983).

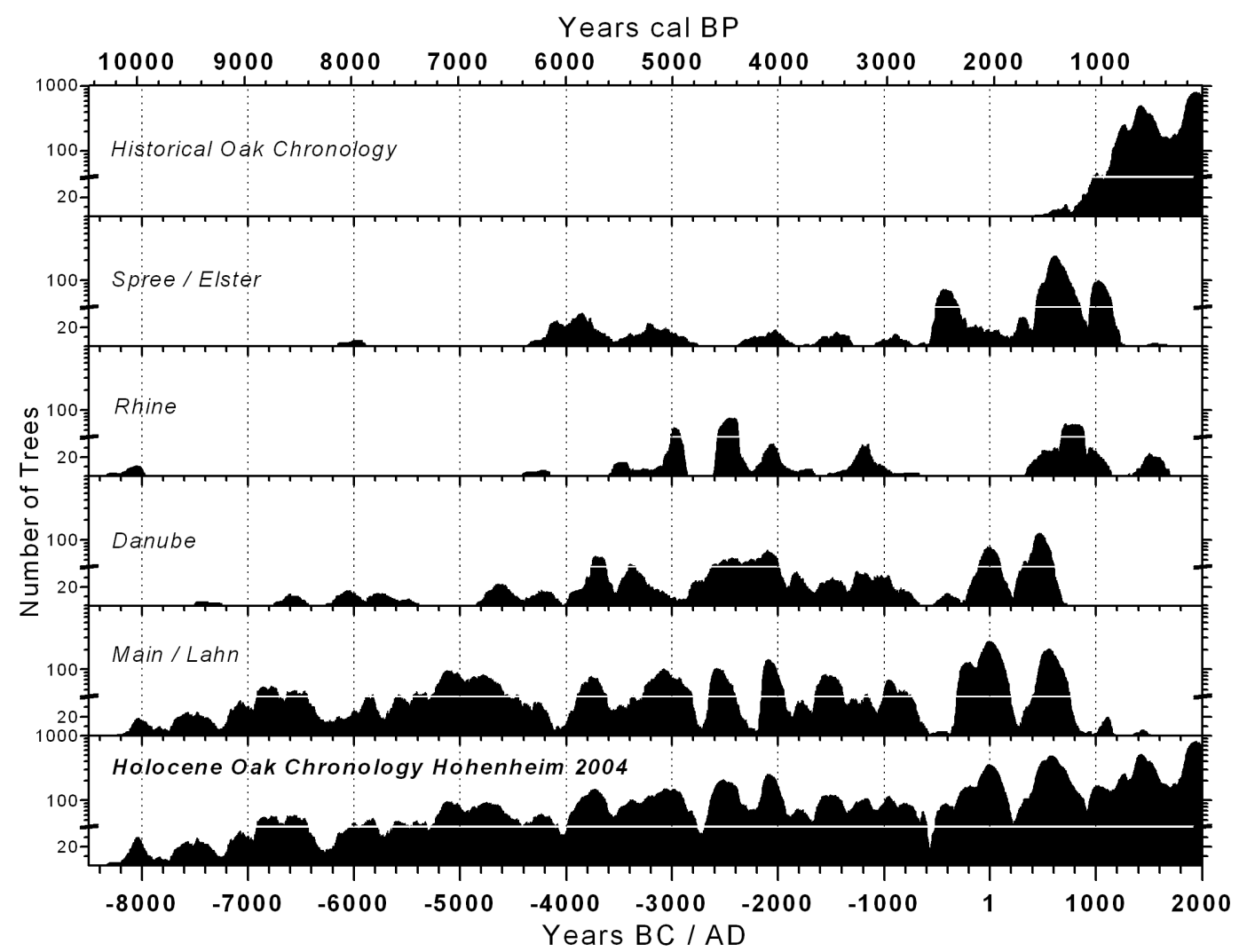

Figure 3 Replication (number of trees through time) of the different regional oak chronologies of the Hohenheim laboratory

For the present state of the Hohenheim HOC, more than 7000 individual oaks were combined. The mean replication is 108 trees per year. We find that $96 \%$ of the length of the chronology is covered by more than 20 crossdated trees. For the historical period (post-AD 500), we use numerous living trees, timbers from buildings, and wood from archaeological excavations to connect the subfossil oaks to the modern chronology, as the finds of subfossil oaks from medieval times are sparse. Even after $30 \mathrm{yr}$ of continuous fieldwork and more than 3000 samples from the river Main alone, a phase of very low replication still exists in the "Hallstatt" period (2600-2300 BP) of that chronology. Fortunately, fluctuations in replication are not synchronous among river valleys, so our work on different regional oak chronologies, and their successful combination, was one of the key factors in obtaining a continuous and well-replicated tree-ring chronology (Figure 3). Whereas for previous versions of the Hohenheim oak chronology (Spurk et al. 1998; Becker 1993) oak samples from prehistoric archaeological sites of Germany and Switzerland (Becker 1985; Friedrich and Hennig 1996) were used to bridge the "Hallstatt gap" and strengthen the prehistoric part of the chronology, the current prehistoric oak chronology is based on subfossil riparian oaks only. 
A compilation is given in Figure 4 of the regional Holocene oak chronologies from southern and eastern Germany along with selected Late Holocene data from historical buildings, archaeological wood, and living trees combined with the "Hohenheim Master Oak Chronology." The combined series runs from 10,430 BP (8480 BC) to modern times (AD 2002). In addition to the statistically significant internal cross-matches between the different regional series, the links were confirmed by comparisons to the independent Irish oak chronology (Pilcher et al. 1984) and the Göttingen oak chronology (Leuschner 1992) back to 9741 BP (7792 BC) (Spurk et al. 1998).

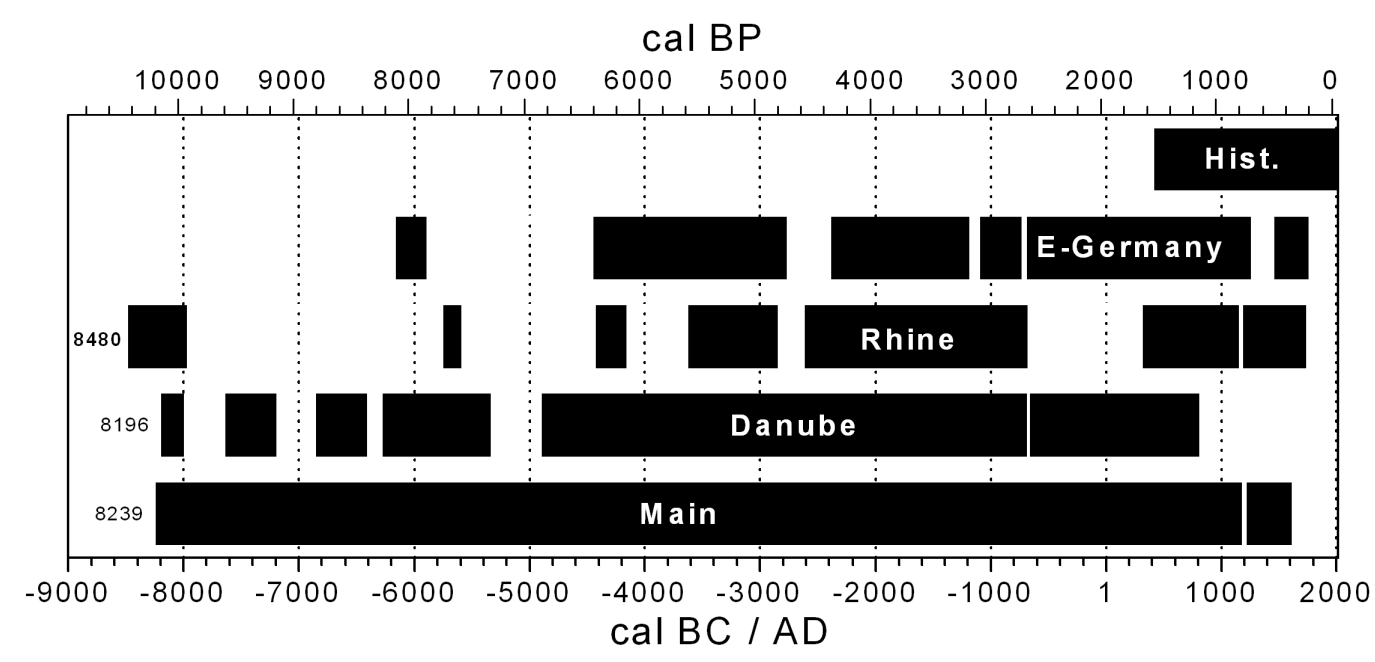

Figure 4 Compilation of the central European Holocene oak chronologies of the Hohenheim laboratory. The blocks represent replicated regional chronologies which were linked dendrochronologically to each other. The chronology from the river Main consists of an unbroken record from $8239 \mathrm{BC}$ to $\mathrm{AD} 1100$. The chronology of oaks from archaeological sites, historical timbers, and living trees connect the prehistoric chronologies to the present. The numbers at the left-hand end of the bars give the calendar year (cal BC) of the oldest oak tree ring in the respective region.

\section{INFLUENCE OF COCKCHAFER PREDATION ON THE OAK CHRONOLOGIES}

Insect pests can strongly influence tree growth and can be much more important for tree growth than any other environmental factor. In oak trees, very regular rhythms in the ring widths are only occasionally observed, leading to considerable difficulties in reliably synchronizing the ring patterns. To some extent, this is because oaks attract various pests, cockchafer being the most important. In Europe, 2 species of cockchafer (Melolontha melolontha L. and M. hippocastani F.) occur. Before intensive pest-control began, rhythmic gradations of cockchafer had occurred within central Europe. Depending on weather conditions and regional situations, at intervals of 3 to $5 \mathrm{yr}$, a substantial number of oaks become defoliated in spring, resulting in a sudden cessation of tree growth. Anatomically, the damage is apparent by narrow tree rings spaced at a period of 3 to $5 \mathrm{yr}$. Specific wood anatomical features allow the clear identification of such years of defoliation. Since the re-occurrence of the beetles is very constant, this influence can come to dominate the interannual tree-ring signal. The consequence of this is that strongly affected trees produce extremely similar tree-ring curves, even if they are of different ages. Hence, reliable dendrochronological dating becomes impossible.

To identify affected tree-ring series, we have constructed artificial sequences to compare with natural tree-ring series using statistical sign tests. Additionally, anatomical features seen in the oak wood assist in detecting years of defoliation. These specific wood anatomical features have been verified on living oaks by extensive manual defoliation experiments (Friedrich, unpublished data). The num- 
ber of oaks influenced by cockchafers differs between regions, which may be explained by different site qualities. Oaks from sites along the river Main are less influenced than those from the Danube, Rhine, and rivers in eastern Germany, where up to $30 \%$ of the trees suffer from cockchafer attack. When checking and reconstructing the Hohenheim tree-ring chronologies, we systematically screened all the ring patterns of our oaks, and all patterns showing the cyclic effects of cockchafer attack have been removed.

The revision of the Hohenheim oak chronologies resulted in chronologies of higher quality, even if the number of trees in parts of the chronologies had to be reduced significantly, while the oak chronology for the river Main remained more or less unchanged. Due to the great number of trees available in the Hohenheim laboratory, the combined Holocene oak chronology remained well replicated throughout its range (Figure 3).

In IntCa198, some data from insect-affected trees were removed from the radiocarbon data set. We carefully checked those trees again and crossdated them on the new chronologies by filtering out the cockchafer signal. Thus, we could re-introduce the ${ }^{14} \mathrm{C}$ data of some of those trees in the IntCal04 calibration data set, complemented and controlled by dates from new, unaffected trees (Reimer et al., this issue).

\section{THE PREBOREAL PINE CHRONOLOGY (PPC)}

In the Late Glacial and Early Holocene, marginal tree habitats in central Europe were dominated by pines. In the Boreal period, the expansion of mixed deciduous woodland (oak, elm, ash, hazel) resulted in a rapid decline of pine when those species entered the southern German river valleys at around 10,450 BP from their sites of refuge in the Mediterranean and Black Sea areas. The oldest dendrochronologically-dated oak trees started to grow at 10,429 BP (8480 BC) (river Rhine), 10,188 BP (8239 BC) (river Main), and 10,145 BP (8196 BC) (river Danube). The youngest dated pine tree died at $7942 \mathrm{BC}$ at the river Danube. Even if the co-dominance of pine and oak in the river valleys was short, it was still sufficiently long to allow a significant overlap. This overlap provides the opportunity to extend the Holocene tree-ring chronologies into the Late Glacial, which was dominated by pine-birch forests. Pine is an important tree species suitable for building long chronologies. The wood is resistant to destruction if deposited in water-filled strata. However, unlike the construction of oak chronologies, tree-ring work with pine is complicated by a tendency for pines to miss rings. Because of this, pine chronologies require high levels of replication to iron out missing ring problems. This is further assisted by the use of independent chronologies from separate sites. Since the 1970s, workers from the Hohenheim laboratory have sampled pine (Pinus sylvestris L.) as well as oak in gravel pits of the German rivers. Whereas the gravels of the river Main provide the majority of Holocene oaks, pines were found only associated with the river Rhine and river Danube and its tributaries (Figure 1). A substantial contribution to the earliest part of the PPC comes from trees found in Avenches (Strasser et al. 1999), Ollon (Hurni et al. 1999), and Zürich (Kaiser 1993), all located in Switzerland.

\section{Dendrochronological Linkage of the Preboreal Pine with the Holocene Oak Chronology}

Until 1998, the PPC was floating with respect to the HOC (Kromer and Spurk 1998; Spurk et al. 1998). The dendrochronological synchronization was expected to be difficult because it involves 2 different species grown in different river valleys. The detailed re-examination of the young end of the PPC and the extension of HOC led to a statistically significant dendrochronological crossdating of the PPC to the HOC (Figure 5) (Friedrich et al. 1999). Both the high-frequency (year-to-year) correlation and the long-term trends agree remarkably well. The grade of uniformity of this interspecies 
cross-match is comparable to northern England subfossil pine and oak comparisons (Chambers et al. 1997) and to cross-matches of modern oak and pine chronologies from southern Germany. Interestingly, the dendrochronological crossdating resulted in a difference of only $8 \mathrm{yr}$ with respect to the published ${ }^{14} \mathrm{C}$ wiggle-match position used for IntCal98 (Kromer and Spurk 1998).

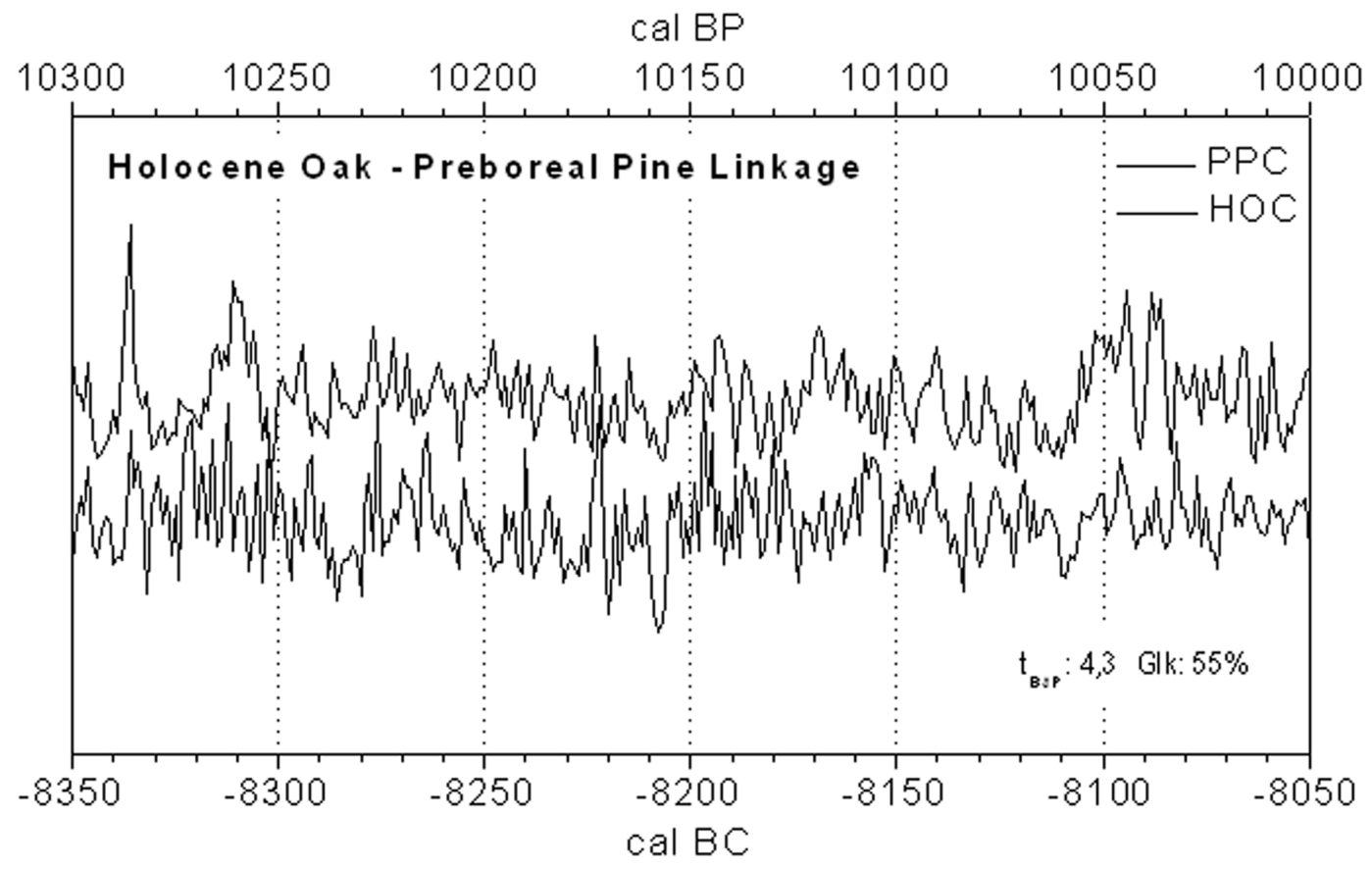

Figure 5 A portion of the dendrochronological linkage of the Preboreal pine chronology (PPC; upper curve) to the Holocene oak chronology (HOC; lower curve). The overlap period of $538 \mathrm{yr}$ allows cross-matching both chronologies significantly. The $\mathrm{t}$-value $\left(\mathrm{t}_{\text {Baillie\&Pilcher }}\right)$ and the Gleichlaeufigkeit (sign test) are given to indicate the similarity.

\section{Linkage of the Two Parts of the PPC}

The PPC as published in 1998 was a two-part chronology linked by high-precision ${ }^{14} \mathrm{C}$ wigglematching and a "tentative" dendrochronological crossdate (Spurk et al. 1998; Kromer and Spurk 1998). By revising the existing chronologies and adding a great number of recently collected pines from southern Germany, we were able to improve and extend the 2 sections of the PPC, and we arrived at a reliable, statistically valid dendrochronological crossdating of both parts of the PPC (Figure 6). The new crossdating results in a shift of $70 \mathrm{yr}$ of the pre-11,250 BP part of the PPC to older ages with respect to the published data (Spurk et al. 1998). Including the 8-yr shift of the oakpine link, the linked PPC now starts at 11,941 BP (9992 BC).

\section{EXTENSIONS OF THE PREBOREAL PINE CHRONOLOGY (PPC)}

Extensive fieldwork, using new sampling strategies and intense cooperation with other tree-ring laboratories that have provided floating chronologies, enabled us to extend our Preboreal pine chronology both at the younger, Holocene end and back into the Younger Dryas:

- Trees from the site of Burlafingen at the river Danube extended the chronology at the young end 17 yr to 9891 BP (7942 BC). 


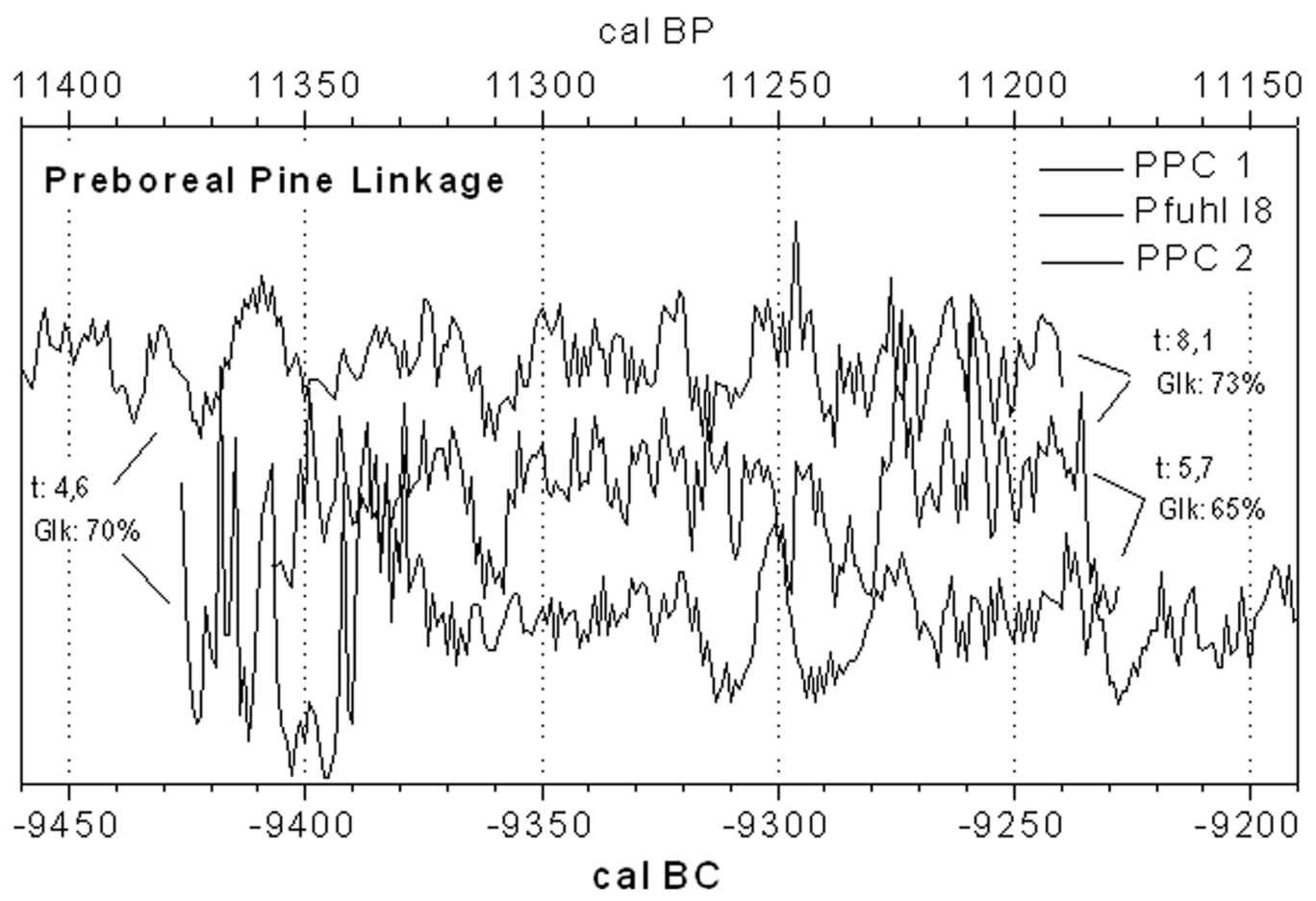

Figure 6 Dendrochronological linkage of the 2 parts of the PPC (PPC1 \& 2). Besides the direct cross-match of PPC1 and PPC2, the sequence Pfuhl 18 (central curve) matches consistently to the absolutely dated PPC2 (lower curve) as well as to the older, floating part PPC 1 (upper curve). The $t$-value as well as the Gleichlaeufigkeit are highly significant. This acts as an additional proof of the cross-match.

- A group of 44 pines from Breitenthal at the river Günz, a small tributary of the Danube, allowed the construction of a $277-\mathrm{yr}$ pine chronology, which strengthened and extended the PPC to 11,993 BP (10,044 BC) (Figure 7).

- The extended PPC then cross-matched the floating chronology of 20 pines from the Swiss site Les Longs Prés, Avenches (Strasser et al. 1999), which were provided by the Laboratoire Romand de Dendrochronologie Moudon, Switzerland. This 415-yr chronology extends the PPC back to 12,057 BP (10,108 BC) (Figure 7). Additionally, a larch tree from Ollon, Switzerland (Hurni et al. 1999) with 363 tree rings could be matched to the Avenches chronology and the PPC and extended them back to 12,142 BP (10,193 BC).

- The floating, 398-yr chronology constructed using 28 trees from a Younger Dryas subfossil pine forest, excavated in the lignite area at Cottbus, eastern Germany (Spurk et al. 1999), was then linked to the PPC, extending the PPC back to 12,325 BP (10,376 BC) (Figure 8).

- Finally, a floating, 215-yr curve of 2 pines from Zürich, Switzerland, provided by the WSL, Birmensdorf (Kaiser 1993), could be matched to the Cottbus chronology and therefore extended the combined new PPC to $12,410 \mathrm{BP}(10,461 \mathrm{BC})$ (Figure 8). As the overlap period relies on only a few trees in both series from different regions, this linkage is still "tentative," even if we found a convincing visual link which can be confirmed by the ${ }^{14} \mathrm{C}$ wiggle-match of both series (Figure 9). 


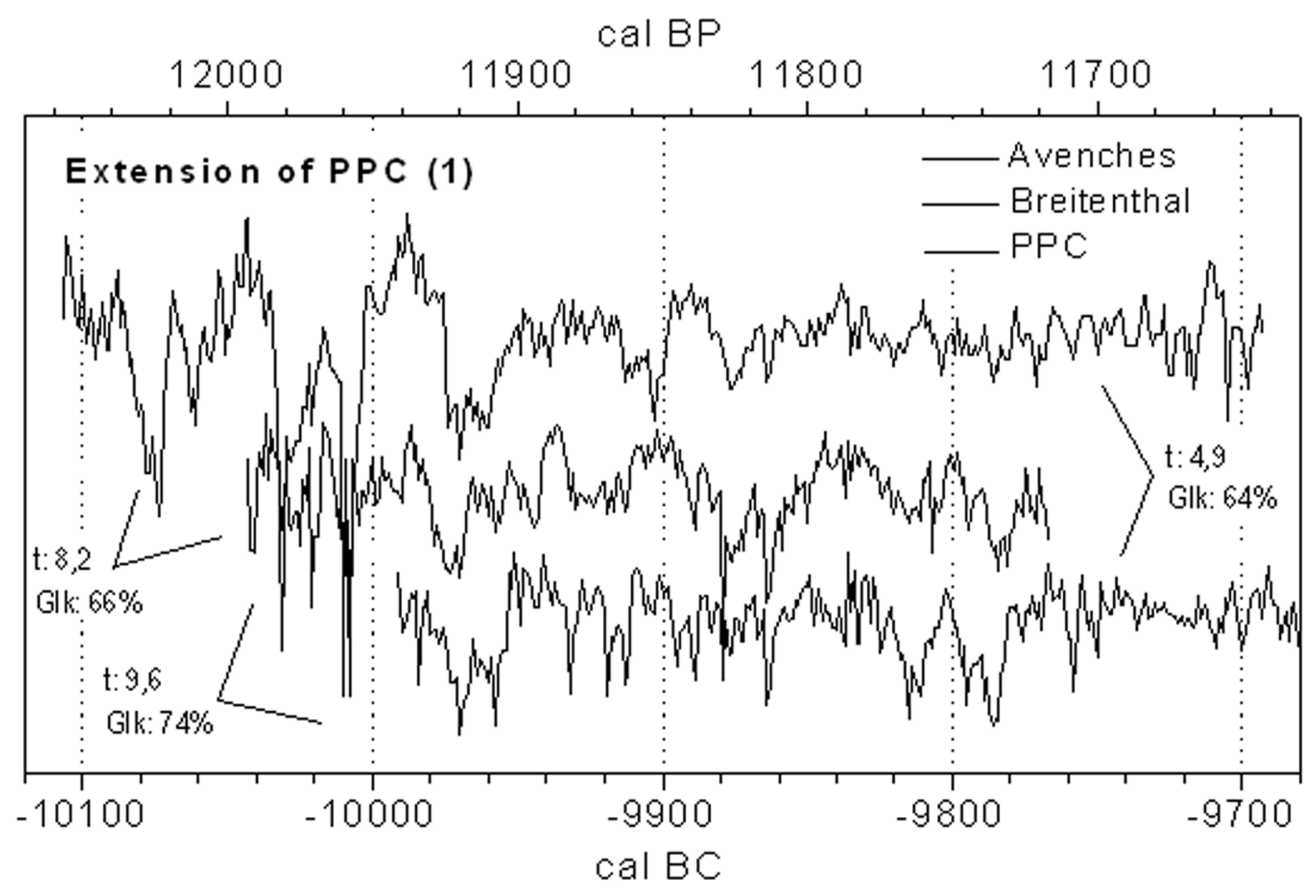

Figure 7 Cross-match of the pine chronologies from Breitenthal (central curve) and Avenches (upper curve) to the absolutely dated PPC (lower curve). The highly significant correlation coefficients [ $t$-value and Gleichlaeufigkeit (sign test)] are given in the graph.

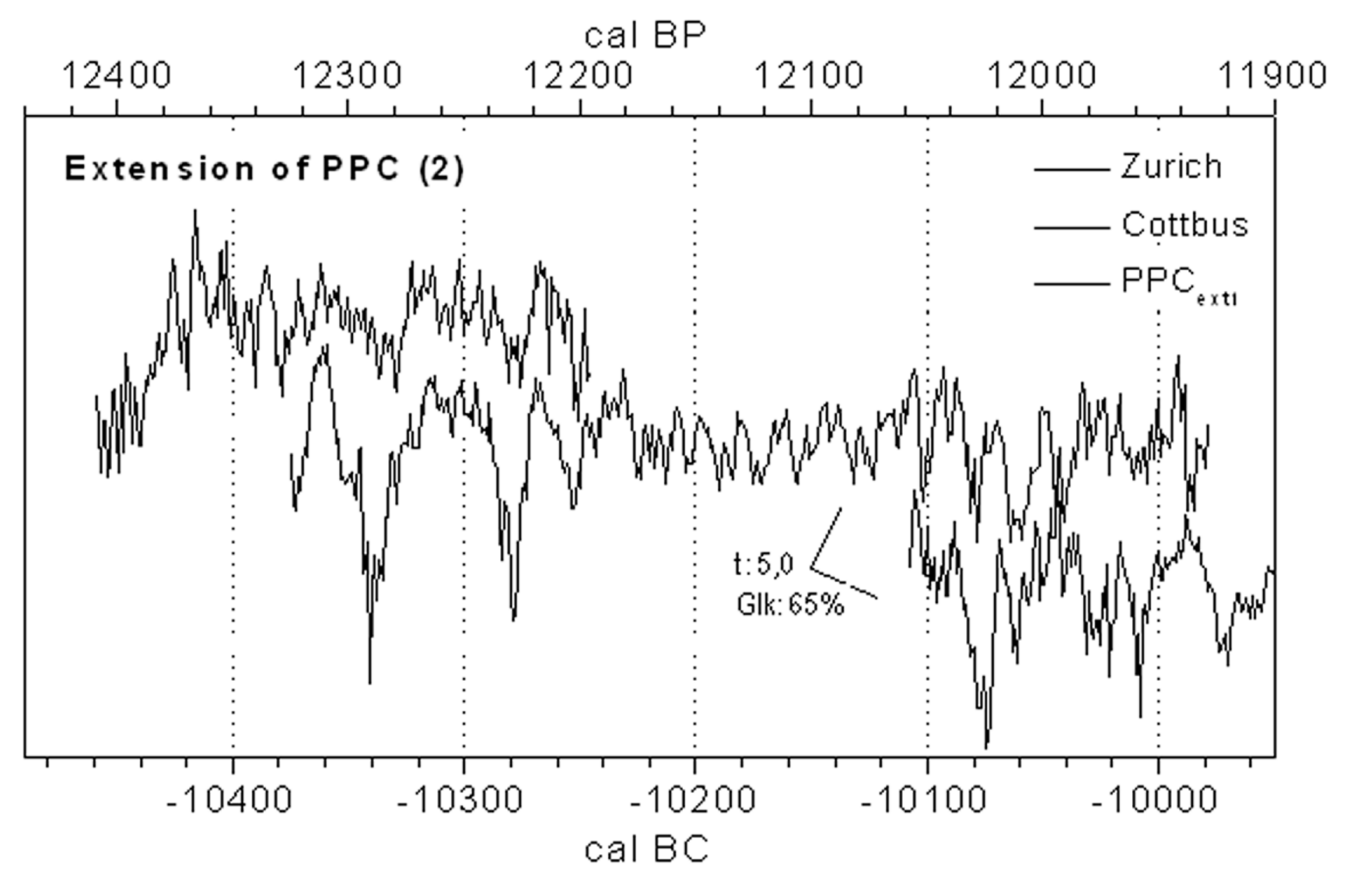

Figure 8 Cross-match of the pine chronology from Cottbus, eastern Germany (central curve), and the extended PPC (lower curve) as well as the match of the Zürich curve (upper curve) on the Cottbus pine chronology. 


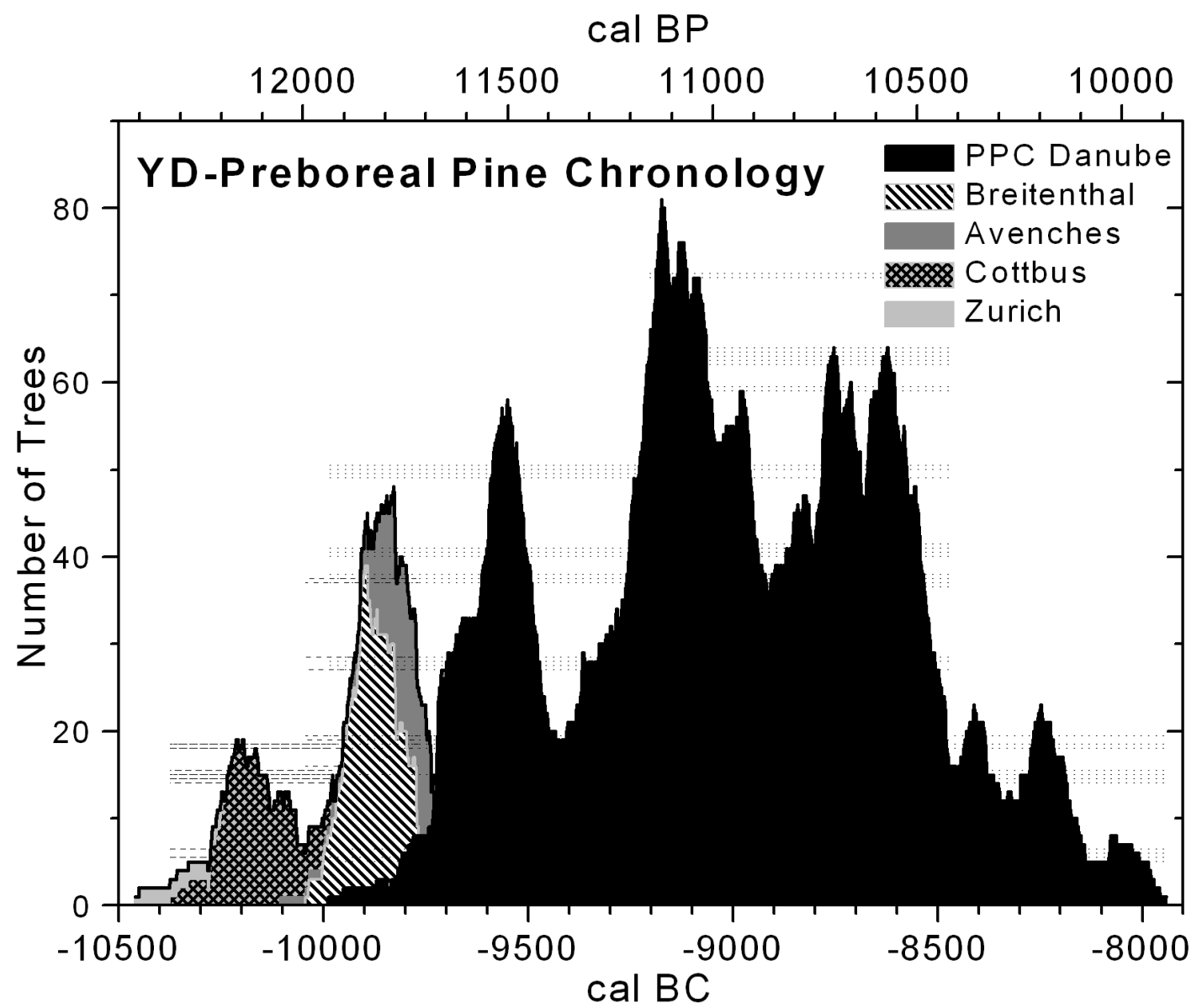

Figure $9{ }^{14} \mathrm{C}$ series obtained from decadal tree rings of the different regional tree-ring series in position of the dendrochronological dates. The dendrochronological linkages are supported by the ${ }^{14} \mathrm{C}$ dates.

cal BC/AD

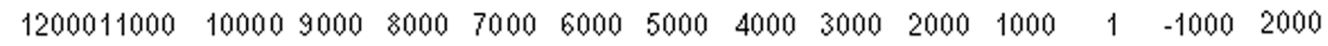

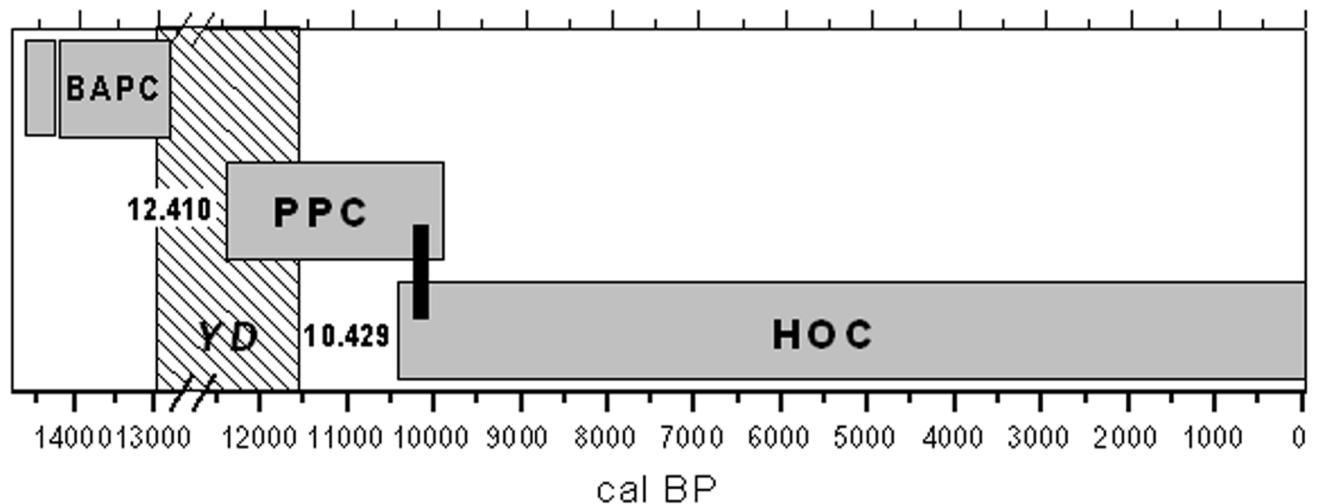

Figure 10 Range and replication of the YD and Preboreal pine chronologies after their revisions and extensions. Pines from the different regions are stacked on each other to show the replication of the combined chronology. 
So far, 515 pines from the valleys of the rivers Danube and Rhine from eastern Germany and Switzerland have been synchronized into a combined 2520-yr pine chronology named the PPC. The main body of the new PPC is constructed from pines of the Danube area. At the older end, trees from eastern Germany and Switzerland make a substantial contribution. The good agreement between the different regional tree-ring chronologies in the YD allowed us to combine regional chronologies over an unusually large area from eastern Germany to Switzerland to form a central European pine chronology (PPC). The replication of the PPC shows fluctuations, which may indicate changes in the hydrological system of the rivers, but with up to 81 trees per year and a mean replication of 30 trees, the PPC is a sufficiently replicated and reliable tree-ring chronology. This new PPC has been linked dendrochronologically to the absolute Holocene oak chronology, extending the absolute, tree-ring-based time scale back to $12,410 \mathrm{BP}(10,461 \mathrm{BC})$.

The Younger Dryas-Preboreal transition is observed in the ring-widths of our pines (Friedrich et al. $1999)$ at 11,590 BP (9641 BC); thus, the absolute tree-ring chronology now covers $820 \mathrm{yr}$ of the Younger Dryas and the entire Holocene. The full range is $12,460 \mathrm{yr}(10,461 \mathrm{BC}-\mathrm{AD} 2000)$.

\section{CONCLUSION AND PROSPECTS}

We have indicated the revisions and extensions of the combined oak and pine tree-ring chronology for central Europe constructed at Hohenheim University. This chronology forms the backbone of the Holocene ${ }^{14} \mathrm{C}$ calibration. The Holocene oak chronology (HOC) has been strengthened by new trees starting at 10,429 BP (8480 BC). Oaks affected by cockchafer predation have been identified and removed from the chronology. The formerly floating Preboreal pine chronology (PPC) has been cross-matched dendrochronologically to the absolutely dated oak chronology. In addition, the 2 parts of the PPC were linked dendrochronologically. Including the 8-yr shift of the oak-pine link, the older part of the PPC (pre-11,250 BP) needs to be shifted 70 yr to older ages with respect to the published data (Spurk et al. 1998). The southern German part of the PPC now covers $2103 \mathrm{yr}$ from 11,993 to 9891 BP (10,044-7942 BC). Furthermore, the PPC was extended significantly by new pine chronologies from Avenches and Zürich, Switzerland, and by the pine chronology from the Younger Dryas forest at Cottbus, eastern Germany. The absolutely dated tree-ring chronology now starts at $12,410 \mathrm{cal} \mathrm{BP}(10,461 \mathrm{BC})$. Therefore, the tree-ring-based ${ }^{14} \mathrm{C}$ calibration now reaches back into the mid-Younger Dryas. With respect to the Younger Dryas-Preboreal transition-identified in the ring-width of our pines as an abrupt increase at 11,590 $\mathrm{BP}$ - the absolute tree-ring chronology now covers the entire Holocene and $820 \mathrm{yr}$ of the Younger Dryas. The Hohenheim chronologies provide an annual time scale for almost $12,500 \mathrm{yr}$, and there is a realistic possibility for further extension into the early Late Glacial (Figure 11).

New finds of huge numbers of subfossil pines from the Bølling-Allerød Interstadial (Greenland Interstadial 1) in Germany and Switzerland enabled us to establish a two-part floating pine chronology of about $1600 \mathrm{yr}$ covering the ${ }^{14} \mathrm{C}$ age of 12,300 to 10,650 BP (chronozones Bølling/Allerød/ early YD) (Friedrich et al. 2001; Kromer et al., this issue). Currently, the remaining gap in the YD is only about $200{ }^{14} \mathrm{C}$ yr. Bridging this gap in the YD and extending the absolute tree-ring chronology, and consequently extending the tree-ring-based ${ }^{14} \mathrm{C}$ calibration into the Bølling-Allerød Interstadial, seems to be feasible in the near future. 


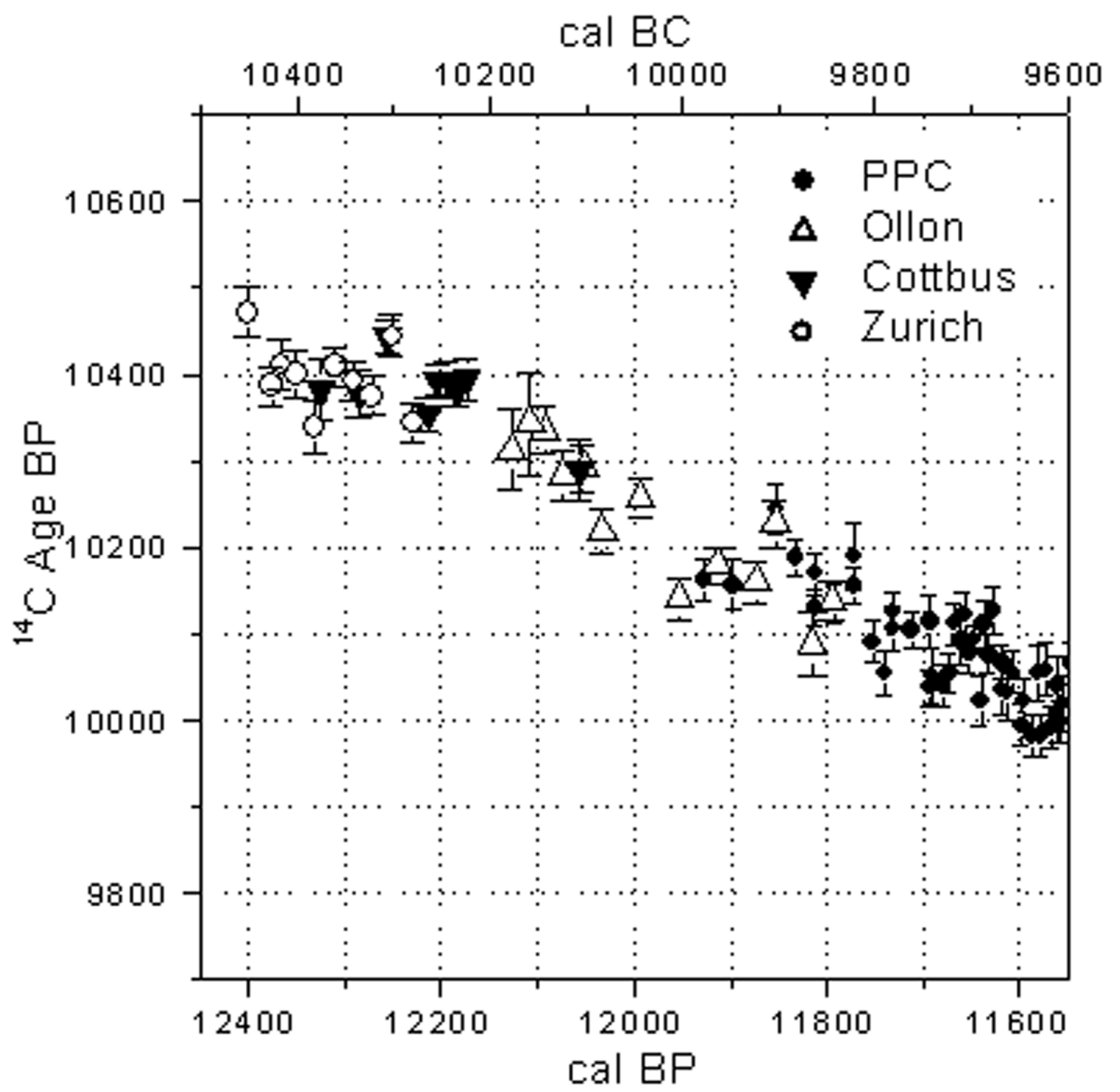

Figure 11 Compilation of the Holocene and Late Glacial tree-ring chronologies of the Hohenheim laboratory. The absolute part of the chronology is given on the tree-ring time scale; the floating parts of the Late Glacial chronologies (Bølling-Allerød pine chronology, BAPC) are given on the Cariaco time scale (Hughen et al. 2000). The Holocene oak (HOC) and the YD-Preboreal pine (PPC) are combined to the absolutely dated chronology starting at $12,410 \mathrm{BP}$. To anchor the floating Bølling-Allerød pine chronology in time, we compared the decadal ${ }^{14} \mathrm{C}$ series of this chronology to the Cariaco varve chronology (Hughen et al. 2000) using the high-frequency ${ }^{14} \mathrm{C}$ fluctuations of both series (Kromer et al., this issue).

\section{ACKNOWLEDGMENTS}

M F and B K received funding for this work from the German Ministry of Education and Research (BMBF, DEKLIM program). We are grateful for the technical assistance of S Papenfuß, A TrebingNiyazi, and numerous student assistants for accurate tree-ring measurements. We thank the Landesamt für Archaeologie Brandenburg for samples from Cottbus, eastern Germany. D Weidmann, Departement des infrastructures, Lausanne, Switzerland, provided samples from Avenches. We thank Mike Baillie for detailed and helpful comments on the paper and revision of the English.

We are especially grateful for discussion with IntCal04 working group members. 


\section{REFERENCES}

Becker B. 1982. Dendrochronologie und Paläoökologie subfossiler Baumstämme aus Flussablagerungen. Ein Beitrag zur nacheiszeitlichen Auenentwicklung im südlichen Mitteleuropa. In: Mitteilungen der Kommission für Quartärforschung der Österreichischen Akademie der Wissenschaften. Band 5.

Becker B. 1983. Postglaziale Auwaldentwicklung im mittleren und oberen Maintal anhand dendrochronologischer Untersuchungen subfossiler Baumstammablagerungen. Geologisches Jahrbuch A 71:45-59.

Becker B. 1985. Die absolute chronologie der Pfahlbauten nördlich der Alpen im Jahrringkalender Mitteuropas. In: Becker B, Billamboz A, Egger H, Gassmann P, Orcel A, Orcel C, Ruoff U, editors. Dendrochronologie in der Ur- und Frühgeschichte. Basel: Verlag Schweizerische Gesellschaft für Ur- und Frühgeschichte. p 8-28.

Becker B. 1993. An 11,000-year German oak and pine dendrochronology for radiocarbon calibration. Radiocarbon 35(1):201-13.

Chambers FM, Lageard JGA, Boswijk G, Thomas PA, Edwards KJ, Hillam J. 1997. Dating prehistoric bogfires in northern England to calendar years by longdistance cross-matching of pine chronologies. Journal of Quaternary Science 12:253-6.

Friedrich M, Hennig H. 1996. A dendrodate for the Wehringen Iron Age wagon grave in relation to other recently obtained absolute dates for the Hallstatt period in southern Germany. Journal of European Archaeology 4:281-303.

Friedrich M, Kromer B, Kaiser KF, Spurk M, Hughen KA, Johnsen SJ. 2001. High resolution climate signals in the Bølling/Allerød Interstadial (Greenland Interstadial 1) as reflected in European tree-ring chronologies compared to marine varves and ice-core records. Quaternary Science Reviews 20(11):1223-32.

Friedrich M, Kromer B, Spurk M, Hofmann J, Kaiser KF. 1999. Paleo-environment and radiocarbon calibration as derived from Late Glacial/Early Holocene tree-ring chronologies. Quarternary International 61:27-39.

Hughen KA, Southon JR, Lehman SJ, Overpeck JT. 2000. Synchronous radiocarbon and climate shifts during the last deglaciation. Science 290:1951-4.

Hurni J-P, Monnard E, Orcel C, Tercier J. 1999. Exploitation dendrochronologique et analyses ${ }^{14} \mathrm{C}$. Mémoires de la Société Vaudoise des Sciences Naturelles 19(3):277-98.

Kaiser KF. 1993. Beiträge zur Klimageschichte vom Hochglazial bis ins frühe Holozän, rekonstruiert mit Jahrringen und Molluskenschalen aus verschiedenen
Vereisungsgebieten [Habilitation thesis]. Winterthur, Birmensdorf: Ziegler Druck- und Verlags-AG.

Kromer B, Friedrich M, Hughen KA, Kaiser KF, Remmele S, Schaub M, Talamo S. 2004. Late Glacial ${ }^{14} \mathrm{C}$ ages from a floating, 1382-ring pine chronology. Radiocarbon, this issue.

Kromer B, Spurk M. 1998. Revision and tentative extension of the tree-ring based ${ }^{14} \mathrm{C}$ calibration, 9200 to 11,855 cal BP. Radiocarbon 40(3):1117-25.

Leuschner H-H. 1992. Subfossil trees. In: Bartholin TS, Berglund BE, Eckstein D, Schweingruber FH, editors. Tree Rings and Environment. Proceedings of the International Dendrochronological Symposium, Ystad, South Sweden, 3-9 September 1990. Lund: Lund University, Department of Quaternary Geology. p 193-7.

Pilcher JR, Baillie MGL, Schmid B, Becker B. 1984. A 7,272-year tree-ring chronology for western Europe. Nature 312:150-2.

Reimer PJ, Baillie MGL, Bard E, Bayliss A, Beck WJ, Bertrand CJH, Blackwell PG, Buck CE, Burr GS, Cutler KB, Damon PE, Edwards RL, Fairbanks RG, Friedrich M, Guilderson TP, Hughen KA, Kromer B, McCormac G, Manning S, Bronk Ramsey C, Reimer RW, Remmele S, Southon JR, Stuiver M, Talamo S, Taylor FW, van der Plicht J, Weyhenmeyer CE. 2004. IntCal04 terrestrial radiocarbon age calibration, 0-26 cal kyr BP. Radiocarbon, this issue.

Spurk M, Friedrich M, Hofmann J, Remmele S, Frenzel B, Leuschner H-H, Kromer B. 1998. Revisions and extensions of the Hohenheim oak and pine chronologies - new evidence about the timing of the Younger Dryas/Preboreal transition. Radiocarbon 40(3):110716.

Spurk M, Kromer B, Peschke P. 1999. Dendrochronologische, palynologische und Radiokarbon-Untersuchungen eines Waldes aus der Jüngeren Tundrenzeit. Naturwissenschaftliche Untersuchungen zum Weichselspätglazial in der Niederlausitz bei Cottbus (Land Brandenburg). Quartär 49/50:34-8.

Spurk M, Leuschner H-H, Baillie MGL, Briffa KR, Friedrich M. 2002. Depositional frequency of German subfossil oaks: climatically and non-climatically induced fluctuations in the Holocene. Holocene 12(6): 707-15.

Strasser A, Weidmann M, Hochhuli PA. 1999. Sédimentation postglaciaire fluviatile et palustre près d'Avenches (Suisse): implications climatique. Bulletin de la Societé Fribourgeoise des Sciences Nataturelles 88:5-26. 